aillardia, and harebell-are at their eak, one could still find late blosoms of violet and white anemone in he long grass under the trees, while the same time goldenrod and sunlower were budding along the sunny ailroad grade.

Besant had other attractions too. the creek, twisting dankly under a lose canopy of willow, widened into wimming hole at one point, at anther, just beside the vellvety lawn rickle where the wee ones splashed. xxcursions along its bank yielded a andful of wild strawberries, a hatul of raspberries or saskatoons. Girls athered wild flowers along the rade, and little boys loved to roam he pitchy hills-but woe to the bare foot that came down on a cactus! There was, too, an open pasture where an impromptu ball diamond could be laid cut.

Here, I remember, in the dry, dry summer of 1948 a Sunday School picnic lunch lay spread, to its last detail, when a sudden splash of rain sent us running to the cars. Late that same summer we came to Besant once again for a cornfeed which almost didn't come off, because the cooks arrived with two coffee pots and no kettle for the corn. However, we cooked it in relays, packed upright in the larger coffiee pot, and had a wonderful time. Food, fire, and friends by a sheltered stream still work their ancient, elemental spell.

\title{
Seen by a Seer
}

\section{By J. BOSWELL BELCHER, Dilke, Sask.}

This time I have three items to eport which I thought were of some nterest.

Considering the name of our magaine, I should probably first report he appearance of two Blue Jays in ur shelter belt early in October of his year. They were the first I had ver seen, and the only ones I have eard of in our district.

The second incident occurred beore the first, on a Saturday afiteroon early in August. I had stopped utting grain in order to make an djustment on the swather, and I eard a most unusual chirping about he. Although there were many rickets in the fields, I thought it as a raither strange chirping for a ricket. However, I knew it wasn't hy machine and surely wasn't interering with its operation, so I gave no more thought and went about yy swathing. Monday when I stoped in the field the strange chirping yas there again. It sounded so much ke house sparrows that I glanced bout to check, but no bird was in ght. As I walked around the wather I noticed the sound on the ther side of me so I became curious nd traced the sound right to its purce, which seemed to be the heavy ipe frame at the back of the swather. hen I realized I had a family of ouse sparrows with me which could ot be reached without disassembling art of the machine. Each morning after that I noticed the parents feeding the young as the swather sat in the yard. They had found the swather, though it was left standing at night some distance from where it had been when the nest was built. One day at noon I even noticed Mr. Sparrow sitting on the post with his beak full of insects waiting for me to come home. I was never home at night till after dark, so the little birds must have gone quite hungry. Fortunately for the sparrows, however, the crop was not maturing too fast and I only swathed during the afternoons most days for the first week. The sparrows kept on chirping as they rode around and around the fields until near the end of the week when they had cut over 200 acres and decided to leave their home on wheels.

Oddly the third incident occurred first. It was shortly after the middle of July and Dad was cutting hay in a very rough slough about a mile and a half from home. He was quite surprised when a little fawn, by its size and actions obviously only days old, scrambled up from behind the cutter bar and scampered into the wheat on his wobbly little legs. Quite aware of the probability of other fawns boing near at hand. Dad thought he'd keep a more careful watch and not have that happen again. But a few rounds later he ran the cutter bar over another tiny fawn, again so well hidden in a 
little depression in the ground that Dad saw no sign of it till it got up and hurried into the whelat as the first one did. Each had let out a cry when the mower went over it, so he was afraid to leave the team standing while he went into the wher to see if the fawns had been hurt. However, they appeared unharmed when they ran away. About a month later we saw one run out from the willows and cattails in a large slough nearby. And how it could run by then-no more wobbly legs. It was the first fawn I had seen, although the adult white-tailed deer have not been too uncommon a sight here in the last seven or eight years. Then about mid-September Dad again saw the pair as they ran out from the high weeds in a vacant yard near the cattail slough when he drove into the yard to empty load of wheat in the barn.

\title{
Bird Notes
}

\section{A QUICK-WITTED YELLOWLEGS}

\section{By FRED W. LAHRMAN, Saskatchewan Museum of Natural History}

While out observing birds on the Wascana Waterfowl Park at Regina at noon on September 4, 1957, I saw a Prairie Falcon (Falco mexicanus) come swinging over the marsh, scaring hordes of shorebirds and ducks. It suddenly swooped swiftly down at a Lesser Yellowlegs (Totanus flavipes) which was standing alone in shallow water approximately 50 yards from me. The Yellowlegs remained motionless until the hawk was almost upon it, then it suddenly dove beneath the water in a duck-like manner, submerging completely, and the lightning-swift talons passed harmlessly over. The Yellowleg: bobbed up a moment later, then flew quickly away. The Falcon did no press the attack and continued on its way. Although shorebirds fre quently bathe and swim, I have n previous observation of one actuall: submerging in water. This unusua escape behavior may have save other Yellowlegs.

\section{BROAD-WINGED HAWK NESTING RECORD AT SPIRIT LAKE}

\author{
By WM. ANAKA, Spirit Lake
}

On May 12, 1957, I identified a Broad-winged Hawk in flight over an extensive wooded area near home. At the time I thought I was fortunate to have seen a rare migrant and a new life species. On May 26 I again located a Broad-winged Hawk in the same area. This time it called and circled, but refused to leave. However, a search failed to locate a nest. Returning on June 2 I did find the nest in a balsam poplar, about 20 feet above the ground. The female flew as I started to climb the tree. In the nest were two eggs.

During the succeeding weeks I visited the nest at weekly intervals. On June 18, the nest contained one egg and one newly-hatched young. At no time during my visits did I find any food in the nest. The nest itself was always freshly lined with aspen poplar leaves. One or both adults were always present, protesting my intrusion.
On July 17 there was a sever wind storm, and on the followin day only one almost fully grow? young hawk was in the nest. Th second one was missing from th immediate area. The one in th nest flew as I climbed up, but wa unable to maintain altitude, so lande on the ground. I replaced it in th nest. Returning on July 21, I foun one young hawk in the nest and th second one perched on a tall stum nearby. Both flew away at my an proach.

I did not visit the nest after th date but often observed one or mor hawks in flight over the area. M last record for this species w: September 1.

Checking with Dr. Stuart Hou: ton, who compiled the list of th Birds of the Yorkton area ( $\mathrm{Ca}$ Ficld Naturalist, 63:215-241), I fir that this is a new species and a ne nesting record for the Yorkton di trict. 